\title{
Remoção de BTEX por fungos em reator aeróbio de escoamento contínuo
}

\author{
BTEX removal by fungi in continuous flow aerobic reactor \\ Kelly Rodrigues', Patrícia Celestino Carvalho de Oliveira², Isabel Cristina de Queiroz Moreira³, \\ Sara Fátima Gomes Firmino ${ }^{4}$, Carlos Ronald Pessoa Wanderley ${ }^{5}$, \\ Rinaldo dos Santos Araújo6, Glória Marinho7
}

\begin{abstract}
RESUMO
Foi estudada a remoção de compostos BTEX (benzeno, tolueno, etilbenzeno e xilenos) em reator de escoamento contínuo e mistura perfeita, com inóculo de Aspergillus niger AN 400, operado sob o tempo de detenção hidráulica (TDH) de 12 horas para avaliar a eficiência do sistema na biorremediação de água poluída com gasolina na presença (Etapa I) e na ausência (Etapa II) de glicose (0,5 g.Lํ.'). A água poluída com gasolina foi preparada na proporção de 10:1000 mL (gasolina:água). Na primeira etapa foi ainda estudada a influência da adição de nutrientes no afluente sobre a eficiência do processo. A adição de nutrientes foi benéfica ao processo e, mesmo com a retirada da glicose, a eficiência foi mantida, devido à metabolização do etanol - presente na gasolina brasileira em $25 \%$ - pelos fungos, sendo ambos fontes de carbono de assimilação mais fácil para obtenção de energia; o etanol e a glicose, foram usados como cossubstratos na degradação dos BTEX. Assim, na Etapa 2, quando somente havia o etanol no meio, chegou-se a percentuais médios de 88\% para benzeno, 90\% para tolueno, 90\% para etilbenzeno, e de 91\% para meta, para e orto-xileno (m, p e o-xileno), com formação de subprodutos fenólicos. A população fúngica predominou no meio ao longo de toda a operação do reator.
\end{abstract}

Palavras-chave: biomassa imobilizada; reator com fungos; compostos fenólicos; degradação de BTEX.

\begin{abstract}
The removal of benzene, toluene, ethylbenzene and xylene (BTEX) compounds by Aspergillus niger AN 400 was studied in a continuous flow reactor which was operated at hydraulic retention time (HRT) of 12 hours evaluate the efficiency of the system in the bioremediation of water polluted with gasoline in the presence (Step 1) and absence (Step 2) of 0.5 g.L.-1 glucose. In the first step it was also studied the influence of the addition of nutrients in the influent on the efficiency of the process. The addition of nutrients was beneficial to the process and, with the removal of glucose, the efficiency was maintained due to the use of ethanol - which is a Brazilian gasoline constituent (25\%) - and was used as co-substrate. Both ethanol and glucose are more easily assimilated carbon and energy sources for fungi and were used as co-substrate in the degradation of BTEX. Thus, in Step 2, when only ethanol was in the biomedia, averages percentage of $88 \%$ for benzene, $90 \%$ in toluene, $90 \%$ ethylbenzene and $91 \%$ for meta, para and ortho-xylene ( $m$, $\mathrm{p}$ and o-xylene) were reached, with the formation of phenolic by-products in between. The fungal population in the middle prevailed throughout the operation of the reactor.
\end{abstract}

Keywords: immobilized biomass; fungal reactor; phenolic compounds; BTEX degradation.

\section{INTRODUÇÃO}

De acordo com Tiburtius, Zamora e Leal (2004), com base em dados contidos em relatório apresentado em 2001 pela Agência Nacional de Águas, no Brasil, cerca de 70\% dos rios que fazem parte das bacias hidrográficas que vão do Sergipe ao Rio Grande do Sul apresentaram altos índices de contaminação, principalmente por efluentes urbanos contaminados pelo vazamento de gasolina de postos de combustível, substâncias lixiviadas de grandes lixões e agrotóxicos.

\footnotetext{
$\square$

'Engenheira Civil. Doutora em Hidráulica e Saneamento pela Escola de Engenharia de São Carlos (EESC) da Universidade de São Paulo (USP). Professora do Programa de PósGraduação em Gestão e Tecnologia Ambiental do Instituto Federal de Educação, Ciência e Tecnologia do Ceará (PPGTA/IFCE), Campus Fortaleza - Fortaleza (CE), Brasil. ${ }^{2}$ Tecnóloga Ambiental e Mestre em Tecnologia e Gestão Ambiental pelo IFCE. Professora do Departamento de Química e Meio Ambiente do IFCE, Campus Fortaleza - Quixadá (CE), Brasil. ${ }^{3}$ Tecnóloga em Saneamento. Assistente na empresa Cortez Engenharia - Fortaleza (CE), Brasil.

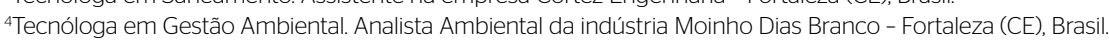

${ }^{5}$ Engenheiro Civil pela Universidade Federal do Ceará (UFC). Mestre em Saneamento Ambiental pela UFC. Professor do curso de Engenharia Ambiental do IFCE, Campus Maracanaú - Maracanaú (CE), Brasil.

${ }^{6}$ Químico Industrial e Doutor em Química pela UFC. Professor do PPGTA/IFCE, Campus Fortaleza - Fortaleza (CE), Brasil.

${ }^{7}$ Farmacêutica pela UFC. Doutora em Saneamento pela EESC/USP. Professora do PPGTA/IFCE, Campus Fortaleza - Fortaleza (CE), Brasil.

Endereço para correspondência: Kelly Araújo Rodrigues Pessoa - Laboratório de Tecnologia Ambiental (LATAM), Instituto Federal de Educação, Ciência e Tecnologia do Ceará (IFCE)- Campus Fortaleza - Avenida 13 de Maio, 2081 - Benfica - 60040-215 - Fortaleza (CE), Brasil - E-mail: kellyarpessoa@gmail.com

Recebido em: 02/02/14 - Aceito em: 15/08/15 - Reg. ABES: 129981
} 
A gasolina é um dos derivados do petróleo mais requisitados no mundo, tratando-se de uma mistura complexa de hidrocarbonetos, a qual apresenta ponto de ebulição entre 30 e $250^{\circ} \mathrm{C}$ e envolve mais de 1.200 compostos de carbono, dentre eles os aromáticos. Os hidrocarbonetos benzeno, tolueno, etilbenzeno e xileno, que possuem o anel benzênico em sua estrutura, são os primeiros constituintes da gasolina que atingem o lençol subterrâneo em casos de vazamentos (SILVA, 2008). Isso ocorre porque eles são os compostos que possuem maior solubilidade em água, com 1.780, 534, 161,2 e 157 mg.L $\mathrm{L}^{-1}$, para benzeno, tolueno, etilbenzeno e xilenos, respectivamente.

Bono et al. (2001) destacaram que os hidrocarbonetos aromáticos provocam vários males à saúde devido à toxicidade e/ou carcinogenicidade do BTEX (benzeno, tolueno, etilbenzeno e xilenos). Os autores também relataram que a inalação de tolueno ou xilenos pode induzir distúrbios no modo de falar, na visão, na audição, no controle dos músculos e outros, além de sugerirem que a associação entre benzeno e xilenos esteja relacionada com o surgimento de tumores cerebrais. Por isso, existe um interesse crescente de se entender o destino e as formas de degradação dos hidrocarbonetos derivados do petróleo em geral visando ao desenvolvimento de métodos mais eficientes de remoção dos mesmos do meio ambiente.

Pesquisadores em todo o mundo buscam novas tecnologias que tornem o processo de degradação do BTEX mais eficiente para que sejam atendidas as exigências por parte dos órgãos ambientais. Os processos devem ser menos onerosos com unidades mais compactas, visando a uma operação mais flexível e com bom desempenho na remoção dos compostos, além de apresentar menor custo de instalação e manutenção.

A utilização de processos biológicos com fungos no tratamento de águas residuárias industriais tem sido bastante estudada, podendo-se citar os trabalhos de D’Annibale et al. (2004), Prenafeta Boldu (2002), García-Peña et al. (2001), Rodrigues (2006), Sampaio (2005) e Lopes et al. (2011), sendo os três últimos referem-se, especificamente, ao emprego da linhagem Aspergillus niger AN400. Trata-se de uma linhagem geneticamente modificada, tendo sido utilizada na remediação de poluentes, como fenóis, nos trabalhos de Rodrigues (2006) e Lopes et al. (2001) - ainda com estudo do consumo de macronutrientes em efluente in natura da indústria da castanha de caju -, e pesticidas, avaliados na pesquisa de Sampaio (2005).

A vantagem em se utilizar fungos está relacionada à sua tolerância a maiores concentrações de produtos tóxicos, à capacidade de crescerem sob condições ambientais de estresse - como em meios com baixos valores de $\mathrm{pH}$, por exemplo - , e, ainda, por suportarem meios pobres em nutrientes (GRIFFIN, 1994). Os fungos apresentam, ainda, segundo Lemos et al. (2008), uma maior capacidade de sobrevivência em meios com baixa atividade de água em relação às bactérias e leveduras.

Conforme a literatura nacional e internacional, poucos são os trabalhos com utilização de fungos na degradação de BTEX, sendo boa parte deles com remoção dos poluentes já a partir da fase gasosa, em correntes de ar submetidas ao tratamento em biofiltros fúngicos, conforme o trabalho de Rene et al. (2012), que empregou Exophialia sp. para a remoção de concentrações de BTEX, variando de 0,06 a 1,43 mg. $\mathrm{L}^{-1}$. São citadas, ainda, as pesquisas de Cheng et al. (2016), que usaram sistema misto de biofiltros, empregando fungos e bactérias na degradação de 0,20 a $1,00 \mathrm{mg} \cdot \mathrm{L}^{-1}$ de tolueno gasoso, e de García-Pena et al. (2001), que utilizaram Pecilomyces variotti no tratamento de gases contendo BTEX, em concentração em torno de $40 \mathrm{mg} . \mathrm{L}^{-1}$.

Dessa forma, o presente trabalho procurou avaliar a viabilidade do uso de fungos na descontaminação de água contaminada pelo contato com a gasolina, o que no cotidiano pode ser observado conforme relatado por Tiburtius, Zamora e Leal (2004). Assim, Aspergillus niger AN400, que é uma linhagem geneticamente modificada para o uso na área de saneamento, foi empregada como inóculo de reator de leito fixo e escoamento contínuo para micorremediação dos BTEX presentes na água após contato com a gasolina.

\section{MATERIAL E MÉTODOS}

\section{Água poluída com gasolina}

A água poluída com gasolina foi feita em laboratório, de acordo com procedimentos descritos em Tiburtius, Zamora e Leal (2004). Durante 12 horas, promoveu-se o contato da água com a gasolina comercial que continha em sua constituição $25 \%$ de etanol. A água utilizada foi oriunda do sistema de abastecimento local e recebeu adição de macro e micronutrientes. Foi preparado um volume total de $20 \mathrm{~L}$ de água e gasolina, em reservatório vítreo, sendo empregada a proporção de $10 \mathrm{~mL}$ de gasolina para cada litro de água, sob temperatura ambiente - em torno dos $25^{\circ} \mathrm{C}$.

Os nutrientes foram adicionados ao meio na seguinte concentração $\left(\mathrm{g} \cdot \mathrm{L}^{-1}\right):\left(\mathrm{NH}_{4}\right)_{2} \mathrm{SO}_{4}(0,2), \mathrm{NaNO}_{3}(1,0), \mathrm{MgSO}_{4}(0,25), \mathrm{K}_{2} \mathrm{HPO}_{4}(0,2)$, $\mathrm{CaCl}_{2} \cdot 2 \mathrm{H}_{2} \mathrm{O}(0,01), \mathrm{CuSO}_{4} \cdot 7 \mathrm{H}_{2} \mathrm{O}(0,08), \mathrm{H}_{2} \mathrm{MoO}_{4}(0,05), \mathrm{MnSO}_{4} \cdot 5 \mathrm{H}_{2} \mathrm{O}$ $(0,05), \mathrm{Fe}_{2}(\mathrm{SO} 4)_{3}(0,05), \mathrm{ZnSO}_{4} \cdot 7\left(\mathrm{H}_{2} \mathrm{O}\right)(0,04)$. As concentrações foram baseadas em trabalhos anteriores que utilizaram fungos no tratamento de águas residuárias: García-Penã et al. (2001), Kapdan \& Kargi (2002) e Rodrigues (2006).

Após o tempo de contato de 12 horas, a fração aquosa foi separada da gasolina por decantação simples, adicionando-se, ainda, o antibiótico estreptomicina 0,03 mg.L-1 (LIU et al., 2008), visando minimizar a ação de bactérias. A água poluída foi, então, utilizada na alimentação do reator, sendo que, previamente, o pH do meio foi ajustado para 4,5 - valor esse propício para o desenvolvimento dos fungos e dentro da faixa ótima para a atividade enzimática máxima para a maioria das enzimas (BOM; FERRARA; CORVO, 2008). 
Amostras da fração aquosa foram coletadas e caracterizadas por cromatografia gasosa com injeção por headspace e parâmetros físico-químicos como amônia, nitrito, nitrato, sulfato, $\mathrm{pH}$, demanda química de oxigênio (DQO) e fenol.

\section{Cultivo dos fungos}

O cultivo e a produção dos fungos foram realizados de acordo com os procedimentos descritos em Sampaio (2005). O fungo Aspergillus niger AN400, cuja linhagem encontrava-se na micoteca do Laboratório de Tecnologia Ambiental (LATAM) do Instituto Federal do Ceará (IFCE), foi cultivado em placas de Petri com meio de cultura Agar Sabouraud Dextrose, acrescido de 0,03 g. $\mathrm{L}^{-1}$ do antibiótico estreptomicina, visando eliminar a proliferação de bactérias, e de $1 \mathrm{~mL}$ de solução Vishniac por litro de meio de cultura.

$\mathrm{O}$ meio foi previamente esterilizado em autoclave a $121^{\circ} \mathrm{C}$, durante 15 minutos. Após a repicagem, as placas com esporos foram incubadas a uma temperatura de $\pm 28^{\circ} \mathrm{C}$ e, após 10 dias, observou-se o crescimento das colônias por toda a superfície das placas, procedendo-se, então, a remoção dos esporos.

No procedimento de remoção dos esporos foi utilizada a solução de Tween 80 a 0,5\% para facilitar a raspagem. Da suspensão formada, $1000 \mathrm{~mL}$ foram transferidos para tubos de ensaio, previamente esterilizados. Cada um dos tubos recebeu $50 \mathrm{~mL}$ da suspensão e ainda mais $950 \mathrm{~mL}$ de água destilada, obtendo-se diluição de 1:20. Os tubos foram agitados em Vórtex. Assim, transferiu-se $20 \mathrm{~mL}$ da solução preparada para a câmara de Neubauer, com profundidade de $0,1 \mathrm{~mm}$ e área mínima de $1 / 400 \mathrm{~mm}^{2}$, sendo levada ao microscópio ótico de campo claro, 400 vezes maior em 16 campos. A partir da contagem dos esporos fúngicos em microscópio foi obtida a concentração da suspensão de esporos, tendo-se adicionado $2 \times 10^{6}$ esporos. $\mathrm{mL}^{-1}$ como tamanho do inóculo.

\section{Reator de leito de escoamento contínuo}

\section{Imobilização da biomassa fúngica}

A biomassa foi imobilizada em manta de polipropileno, cortada em quadrados de $2 \times 2 \mathrm{~cm}$, os quais foram acondicionados em redes de polietileno e colocados no interior de frascos Erlenmeyer de $250 \mathrm{~mL}$, que receberam $200 \mathrm{~mL}$ de água deionizada acrescida dos mesmos macro e micronutrientes empregados quando do preparo da água poluída de BTEX, nas mesmas concentrações mencionadas anteriormente, além da adição de glicose ( 5 g. $\left.\mathrm{L}^{-1}\right)$ para o crescimento do biofilme fúngico e cloranfenicol $\left(0,10\right.$ g.L $\left.\mathrm{L}^{-1}\right)$.

Os frascos permaneceram sob agitação de $150 \mathrm{rpm}$ durante 72 horas, de modo que, ao completarem 24 horas, o meio antigo foi substituído por um novo. As mantas foram previamente lavadas com água destilada e autoclavadas antes do início do processo de crescimento do biofilme.
Após a imobilização da biomassa, as mantas foram transferidas para o reator de leito fixo e fluxo ascendente para sua partida.

Na Figura 1 são mostrados em detalhes os fungos que crescem imobilizados ao suporte.

\section{Montagem e operação do reator contínuo}

O reator de leito fixo e escoamento contínuo ascendente foi construído em acrílico, possuindo estrutura cilíndrica e volume total de 4,5 L, diâmetro externo de $100 \mathrm{~mm}$, espessura das paredes de $5 \mathrm{~mm}$ e altura de $0,8 \mathrm{~m}$, com entrada para afluente, saída para efluente e entrada para aeração, fornecida por mini-compressor de ar — vazão de ar de $150{\mathrm{~L} . \mathrm{h}^{-1}}^{-1}$ e potência de $5 \mathrm{~W}-$, conforme mostrado na Figura 2.

Ao longo do eixo longitudinal dos reatores foram colocados contentores e placas perfuradas de PVC, possuindo em seu centro uma passagem para uma haste em inox, fixada por encaixe no fundo do reator, com a função de evitar o deslocamento do meio suporte e seu consequente arraste do reator.

Antes da partida do reator, a biomassa de Aspergillus niger AN400, imobilizada em manta de poliuretano, foi adicionada ao mesmo. O reator foi alimentado com água contaminada com gasolina, como descrito anteriormente, quando do preparo da água.

A operação dos reatores foi dividida em duas etapas de alimentação:

- Etapa I: com adição de 0,5 g.L.-1 de glicose no afluente; e

- Etapa II: sem adição de glicose no afluente (Tabela 1).

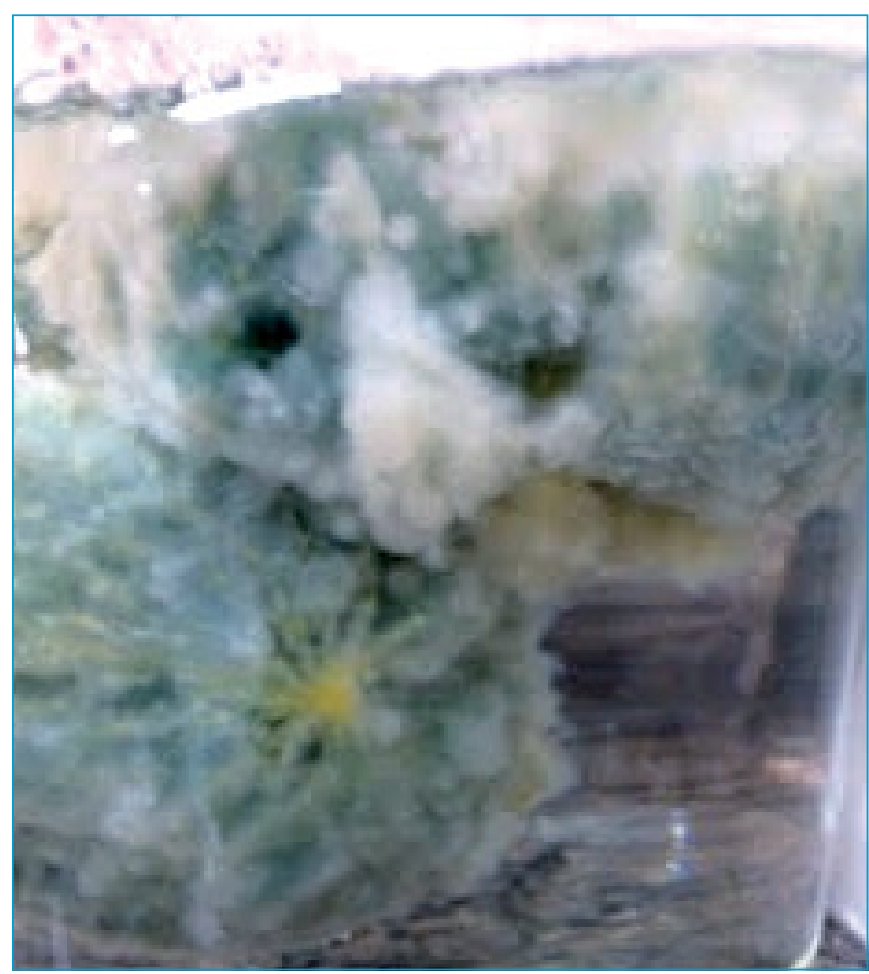

Figura 1 - Fungos da linhagem Aspergillus niger AN400 em crescimento sobre a manta de polipropileno, acondicionada em redes de polietileno, utilizada como material suporte no reator de escoamento contínuo. 
A Etapa I foi dividida em duas fases distintas, segundo a não adição (Fase 1) e adição de nutrientes (Fase 2) no afluente, sendo a Fase 1 correspondente às coletas de 1 a 5 e a Fase 2 às coletas de 6 a 10. Na Etapa II foi mantida a adição de nutrientes.

\section{Ensaio de volatilidade}

O ensaio de volatilidade foi realizado para verificar o potencial de volatilização dos compostos BTEX nas condições operacionais do reator contínuo aerado sem adição de biomassa e de material suporte, a fim de comprovar a menor relevância da volatilização dos BTEX para sua remoção da fase aquosa.

Foi adotado tempo de detenção hidráulica (TDH) de 12 horas, sendo a concentração de benzeno de 4,07 mg.L $\mathrm{L}^{-1}$, tolueno de 7,14 mg.L-1 ${ }^{-1}$, etilbenzeno de $0,42 \mathrm{mg} . \mathrm{L}^{-1}$, meta e para-xileno (m e p-xileno) de $0,79 \mathrm{mg} . \mathrm{L}^{-1}$ e orto-xileno (o-xileno) de $0,79 \mathrm{mg} \cdot \mathrm{L}^{-1}$, as quais são acompanhadas ao longo de intervalos de tempo de 0,$0 ; 0,5 ; 1,0 ; 2,0 ; 2,5 ; 3,0 ; 3,5 ; 4,0 ; 5,0 ; 6,0$; 7,0; 8,0 e 9,0 horas. A volatilidade dos compostos foi avaliada a partir da sua diferença na entrada e na saída do reator.

\section{Ensaio de adsorção}

O ensaio de adsorção foi realizado no reator de leito fixo, a fim de verificar a remoção dos BTEX considerando a condição abiótica para a remoção dos poluentes, ou seja, por adsorção dos BTEX no conjunto manta de polipropileno, material suporte empregado, e, por consequência, nas paredes do reator.
Para isso, a manta de polipropileno foi cortada em cubos de $2 \times 2 \mathrm{~cm}$, resultando em $45 \mathrm{~g}$ de meio suporte.

Foi adotado experimentalmente o TDH de 12 horas e a concentração de BTEX acompanhada ao longo de intervalos de tempo preestabelecidos, a cada hora, até o ponto de saturação no meio suporte, obtido a partir dos dados de concentração de BTEX (entrada e saída), da vazão resultante do TDH $\left(4,2 \mathrm{~L}^{\mathrm{h}} \mathrm{h}^{-1}\right)$, da variação do tempo (0,5 hora) e do volume útil do reator.

\section{Contagem do número de colônias}

Foi realizada a contagem do número de colônias dos micro-organismos por meio do procedimento de diluição em série com uso do meio seletivo Martin, empregado para fungos, o qual foi preparado com $1000 \mathrm{~mL}$ de água destilada e os seguintes constituintes (g.- $\left.\mathrm{L}^{-1}\right): \mathrm{K}_{2} \mathrm{HPO}_{4}(1)$; peptona (5); $\mathrm{KH}_{2} \mathrm{PO}_{4}(5) ; \mathrm{MgSO}_{4} .7 \mathrm{H}_{2} \mathrm{O}(0,5)$; dextrose (10); extrato de levedura $(0,5)$;

Tabela 1 - Cronograma de operação do reator de escoamento contínuo e leito fixo.

\begin{tabular}{c|c|c}
\hline \multirow{2}{*}{$\begin{array}{c}\text { TDH } \\
\text { (horas) }\end{array}$} & Etapa de alimentação & $\begin{array}{c}\text { Tempo de operação } \\
\text { (meses) }\end{array}$ \\
\cline { 2 - 3 } 12 & Etapa I - Fase 1 & 0,75 \\
\cline { 2 - 3 } & Etapa I - Fase 2 & 0,75 \\
\cline { 2 - 3 } & Etapa II & 3,00 \\
\hline
\end{tabular}

TDH: tempo de detenção hidráulica.

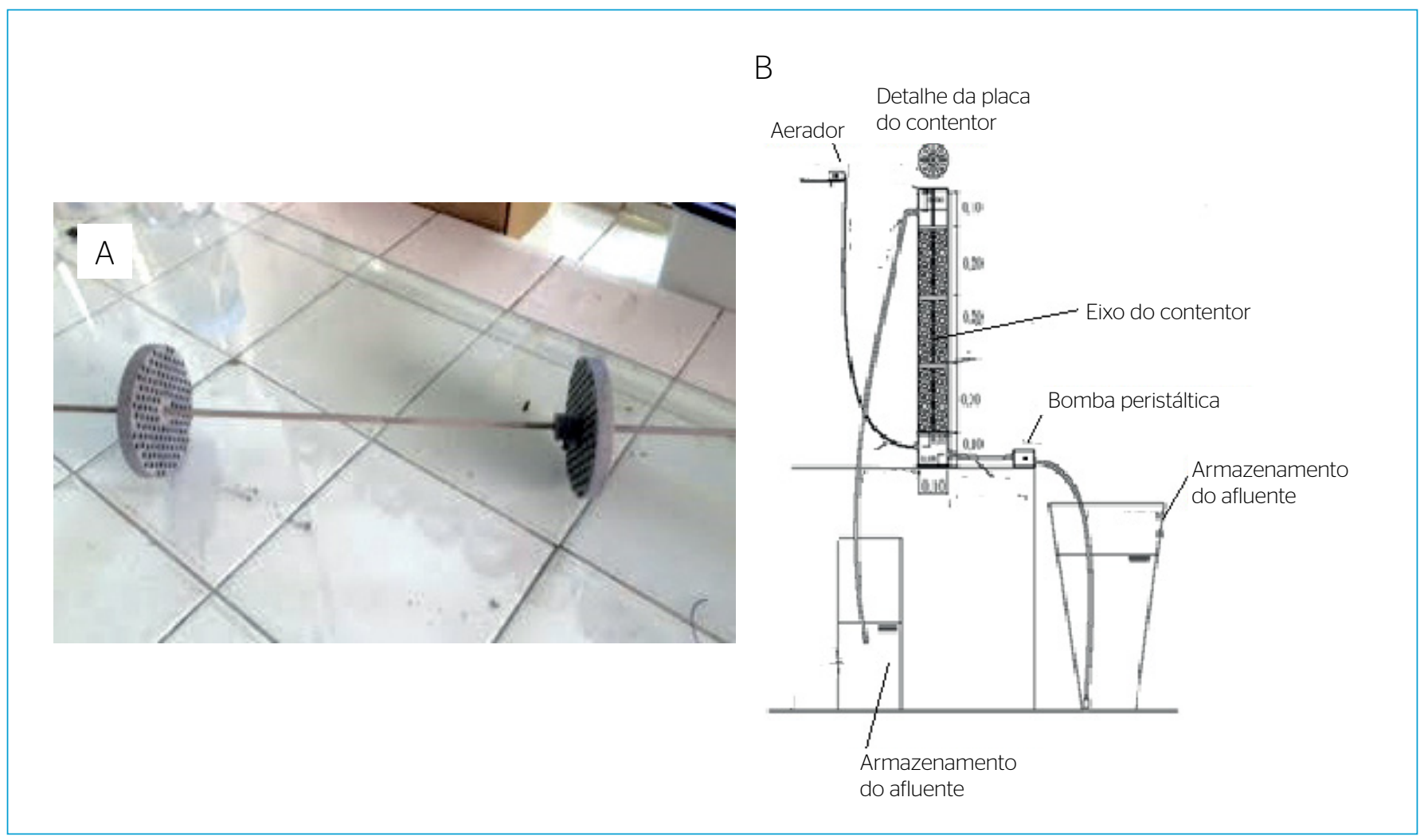

Figura 2 - A) Eixo com os contentores de suporte a serem inseridos verticalmente no reator; B) esquema do reator de leito fixo e escoamento ascendente utilizado na pesquisa para o tratamento de água contaminada com BTEX. Adaptado de Rodrigues (2006). 
rosa bengala $(0,033)$ e ágar (18). O antibiótico estreptomicina $\left(3 \mu \mathrm{g} \cdot \mathrm{mL}^{-1}\right)$ foi adicionado ao meio para evitar a contaminação do meio por bactérias.

Foram retiradas amostras de $10 \mathrm{~mL}$ do conteúdo líquido do reator em operação, misturando-as com $90 \mathrm{~mL}$ de solução salina (0,89\%) em tubo de ensaio de $20 \mathrm{~mL}$, que foi submetido à agitação em vórtex durante 10 minutos.

Em seguida, alíquotas de $0,1 \mathrm{~mL}$ foram retiradas das diluições correspondentes a $10^{-2}, 10^{-3} \mathrm{e} 10^{-4} \mathrm{e}$ adicionadas às placas contendo o meio Martin para fungos. Para promover o espalhamento das colônias, foi utilizada a alça de Drigalski.

Posteriormente, as placas foram incubadas à temperatura de $28^{\circ} \mathrm{C}$ em estufa, durante cinco dias, para permitir o crescimento das colônias fúngicas. A contagem foi realizada pela identificação visual das colônias fúngicas formadas na placa após o período de incubação e multiplicado pelas diluições correspondentes a cada placa.

Paralelamente, amostras dos fungos em placas foram fixadas em lamínulas e submetidas à análise em microscópio óptico com câmera de captura de imagem para identificação dos micro-organismos.

Também foi feito o procedimento para a contagem de colônias bacterianas. Para isso, foi utilizada a técnica de diluições em série, em que foram retiradas alíquotas das diluições correspondentes a 10 $0^{-5}, 10^{-6}$ e 10 $10^{-7}$ e adicionadas às placas contendo o meio Nutriente Ágar. As placas foram incubadas à temperatura de $28^{\circ} \mathrm{C}$ e a contagem realizada após três dias.

\section{Métodos utilizados para a determinação das variáveis}

Todas as análises físico-químicas foram realizadas segundo métodos descritos em APHA (2005), exceto o nitrato — segundo Rodier (1975) - e o fenol, segundo NBR 10740, (ABNT, 1989).

A determinação da concentração de BTEX foi realizada por meio de cromatografia, com uso de cromatógrafo gasoso Perkin Elmer - modelo Clarus 500 - com detector de ionização por chama acoplado a um amostrador headspace (GC/FID/HS), com $5 \mathrm{~mL}$ da amostra no frasco de headspace por 30 minutos padronizados para posterior injeção. Foi utlizada a coluna capilar Elite-5 - 30 m, 0,25 mm e 0,25 $\mu \mathrm{m}$. As condições cromatográficas foram: nitrogênio como gás de arraste $\left(1,0 \mathrm{~mL} \cdot \mathrm{min}^{-1}\right)$, volume de injeção de $1 \mu \mathrm{L}$, injetor a $280^{\circ} \mathrm{C}$, detector a $280^{\circ} \mathrm{C}$, temperatura inicial do forno de $50^{\circ} \mathrm{C}$ por 2 minutos, seguido de rampa de aquecimento $\left(5^{\circ} \mathrm{C} \cdot \mathrm{min}^{-1}\right)$ até a temperatura final de $100^{\circ} \mathrm{C}$ com permanência de 1 minuto.

\section{RESULTADOS E DISCUSSÕES}

\section{Caracterização da água contaminada por gasolina}

$\mathrm{Na}$ Tabela 2, são apresentados os valores médios e desvios-padrão para as variáveis monitoradas no afluente do reator de leito fixo e fluxo contínuo na Etapa 1 - caracterizada pela adição de 0,5 g.L $\mathrm{L}^{-1}$ de glicose e na Etapa II - caracterizada pela ausência de glicose.
Os resultados obtidos mostraram que no afluente os valores de desvios-padrão foram elevados, o que indicou a homogeneidade baixa dos compostos BTEX presentes na água contaminada com gasolina que alimentava o reator. Esse fato é atribuído à variação da própria composição da gasolina tipo C, utilizada no preparo da água poluída, a qual tem composição variável, ainda que ela tenha sido adquirida em posto padrão com bandeira.

Segundo Takeshita (2006), a gasolina é uma mistura complexa de hidrocarbonetos voláteis, cuja composição relativa e características são variáveis e dependem da natureza do petróleo que a gerou e da finalidade para a qual foi produzida. Além disso, o autor ressaltou a ocorrência frequente da prática de adulteração da gasolina, que envolve a modificação da sua composição original por meio da adição de álcool etílico anidro em porcentagens superiores ao estabelecido pela Agência Nacional do Petróleo (ANP) e adição de diversos solventes, como rafinados petroquímicos, tolueno e diesel. Essa prática provoca intensas alterações nas propriedades físico-químicas da gasolina.

Contudo, apesar das variações afluentes observadas, o efluente não apresentou oscilações elevadas de suas características, mostrando que houve facilidade de adaptação dos fungos à variação da concentração das variáveis investigadas e a consequente estabilidade do sistema, mantendo-se a qualidade do efluente final.

É importante mencionar que, ao fazer um comparativo entre as Etapas I e II, houve menor concentração de nutrientes - amônia, nitrato e fósforo - no afluente da Etapa I, pois, antes do reator passar a operar com alimentação com BTEX, o reator foi mantido alimentado com água e nutrientes, conforme descrito no Material e Métodos. Porém,

Tabela 2 - Caracterização da água poluída com gasolina, a qual alimentou o reator nas Etapas I - com adição de 0,5 g. $\mathrm{L}^{-1}$ de glicose - e II - sem adição de glicose.

\begin{tabular}{l|c|c}
$\begin{array}{l}\text { Variável } \\
\text { (mg. L-1) }\end{array}$ & $\begin{array}{c}\text { Etapa I } \\
\left(\mathrm{mg} \cdot \mathrm{L}^{-1}\right)\end{array}$ & $\begin{array}{c}\text { Etapa II } \\
\left(\mathrm{mg} \cdot \mathrm{L}^{-1}\right)\end{array}$ \\
\hline Amônia & $72,500 \pm 31,100$ & $117,800 \pm 14,300$ \\
\hline Nitrito & $0,000 \pm 0,000$ & $0,008 \pm 0,020$ \\
\hline Nitrato & $23,500 \pm 15,700$ & $36,000 \pm 10,600$ \\
\hline Fósforo total & $10,300 \pm 10,200$ & $20,400 \pm 6,700$ \\
\hline Sulfato & $*$ & $177,000 \pm 18,200$ \\
\hline pH & $3,900 \pm 0,070$ & $3,900 \pm 0,400$ \\
\hline DQO & $3396,400 \pm 455,000$ & $2350,000 \pm 566,000$ \\
\hline Benzeno & $7,900 \pm 7,100$ & $7,500 \pm 3,500$ \\
\hline Tolueno & $12,200 \pm 11,100$ & $17,000 \pm 9,600$ \\
\hline Etilbenzeno & $2,100 \pm 1,700$ & $2,000 \pm 1,200$ \\
\hline m, p-xileno & $2,700 \pm 2,500$ & $1,900 \pm 0,900$ \\
\hline o-xileno & $3,500 \pm 2,500$ & $2,600 \pm 1,200$ \\
\hline Fenol & $*$ & $3,300 \pm 2,800$
\end{tabular}

*Não foi possível realizar as análises de fenol e sulfato na Etapa I. DQO: demanda química de oxigênio. 
esse procedimento foi realizado sem adição de BTEX e glicose (1 g.L $\left.\mathrm{L}^{-1}\right)$, tendo, após alguns dias nessa condição, apresentado colmatação de seu leito suporte pelo crescimento exagerado do Aspergillus niger AN 400. Então, optou-se por retirar os nutrientes da coleta 1 até a 5 (Fase I), de modo que, a partir da coleta 6 até a 10, houve adição tanto de glicose quanto de nutrientes (Fase II), visando verificar melhor, novamente, o desenvolvimento da biomassa fúngica.

$\mathrm{Na}$ Etapa I, foram alcançados os percentuais de remoção de $96 \%$ na Fase 1 e $97 \%$ na Fase 2 para benzeno; 95\% e 93\% para tolueno, respectivamente; $65 \%$ e $79 \%$ para etilbenzeno; $89 \%$ e $86 \%$ para m e p-xileno e $87 \%$ e $88 \%$ para o-xileno. Ao se comparar as duas fases, evidenciou-se que a adição de nutrientes não resultou, estatisticamente, em uma diferença significativa nas eficiências de remoção dos poluentes. Os dados experimentais foram obtidos pelo teste $t$ de Student não paramétrico, indicando que as eficiências de remoção nas duas fases foram semelhantes $(p>0,05)$ para benzeno, tolueno, etilbenzeno, $\mathrm{m}$, p-xileno e o-xileno.

Nas Figuras 3 e 4, são apresentadas as concentrações de benzeno, tolueno, etilbenzeno, $\mathrm{m}$ e p-xileno e o-xileno do afluente e efluente ao reator de leito fixo e fluxo contínuo com fungos nas Etapas I e II, respectivamente.

$\mathrm{Na}$ Etapa II, as remoções médias foram de $88 \%$ para benzeno, $90 \%$ para tolueno, $90 \%$ para etilbenzeno, e de $91 \%$ para m, p e o-xileno.

Estatisticamente, ao se comparar a Etapa I com a II, não houve diferença nas eficiências de remoção para tolueno, $\mathrm{m}$ e p-xileno e o-xileno ( $\mathrm{p}>0,05)$. No entanto, as eficiências de remoção de benzeno
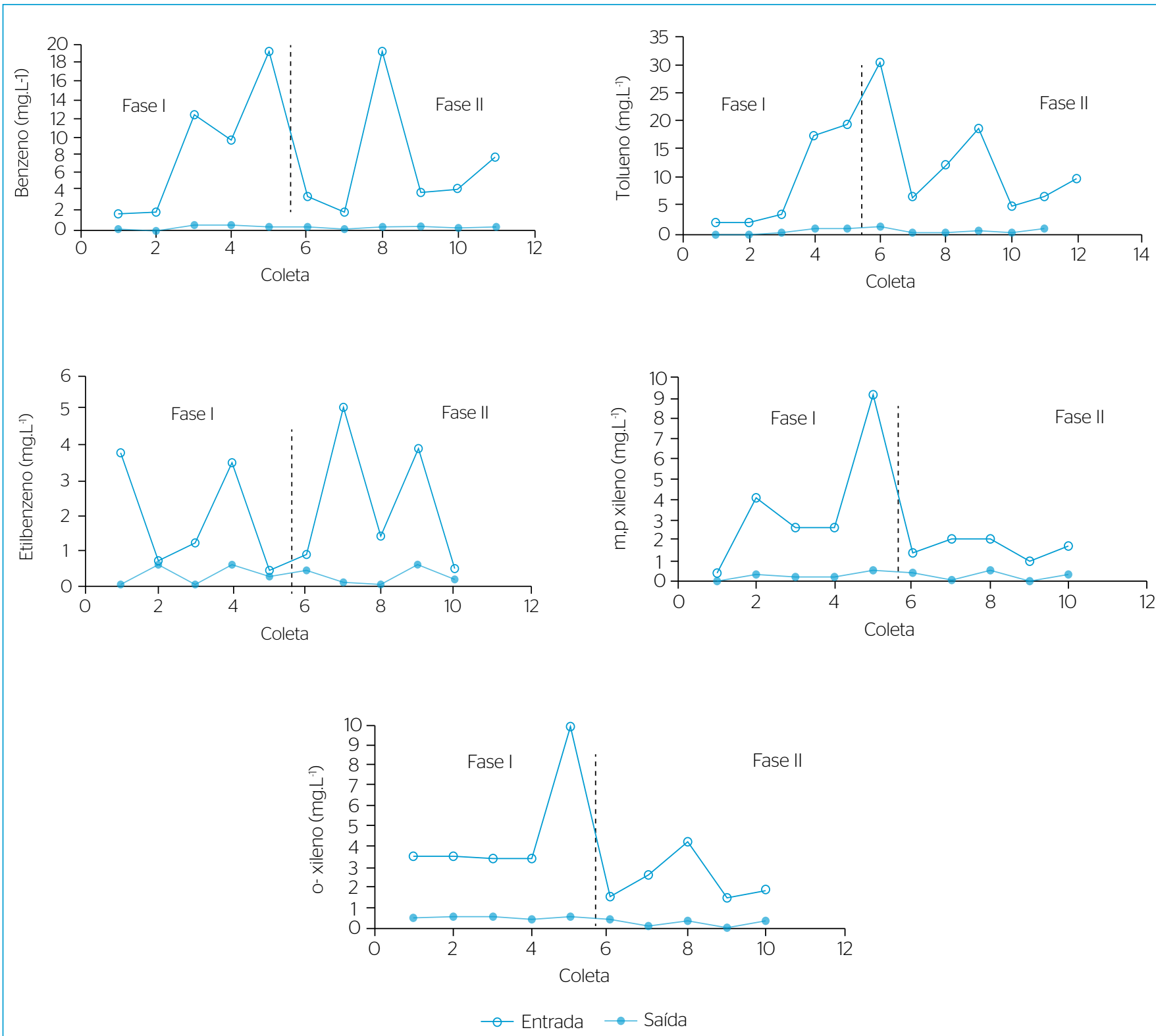

Figura 3 - Concentração de benzeno, tolueno, etilbenzeno e xileno no afluente e efluente ao reator de leito fixo e fluxo contínuo ao longo das coletas da Etapa I. 
e etilbenzeno apresentaram diferença significativa $(\mathrm{p}<0,05)$. Isso demonstrou que houve diminuição da eficiência de remoção de benzeno de 96\% (Etapa I) para 88\% (Etapa II) e aumento da eficiência de remoção de etilbenzeno de 72\% (Etapa I) para 90\% (Etapa II).

A presença de glicose favoreceu a obtenção de melhores percentuais de remoção de benzeno na Etapa I. Estudos demonstram que a utilização de fonte de carbono mais facilmente assimilável é benéfica na biodegradação de alguns compostos recalcitrantes, pois favorece o aumento de biomassa e ganho de energia resultando em melhores remoções desses compostos (WANG et al.,2013).

$\mathrm{Na}$ Etapa II, o aumento da eficiência observado foi atribuído à retirada da glicose do meio. Dessa forma, a presença da glicose teria contribuído para que os microrganismos a consumissem preferencialmente em relação ao etilbenzeno. Segundo García-Peña et al. (2001), esse composto possui maior resistência de ser biodegradado do que os outros hidrocarbonetos presentes, como o tolueno, por exemplo.

Nardi et al. (2005) utilizaram um reator horizontal de fluxo contínuo e leito anaeróbio para remoção de BTEX; o TDH aplicado foi de 11,4 horas. As concentrações médias iniciais para cada composto foi de 14,3 mg.. $\mathrm{L}^{-1}$ de benzeno, 12,8 mg.L $\mathrm{L}^{-1}$ de tolueno, 11,6 mg.L $\mathrm{L}^{-1}$ de etilbenzeno, $23 \mathrm{mg} . \mathrm{L}^{-1}$ de m e p-xileno e 11,9 mg.L $\mathrm{L}^{-1}$ de o-xileno. Ao final do experimento foram alcançados os percentuais médios de remoção de $84,6 \%$ de benzeno, $86 \%$ de tolueno, $86 \%$ de etilbenzeno, $85 \%$ de $\mathrm{m}$ e p-xileno e $84 \%$ de o-xileno. Os resultados alcançados na pesquisa de

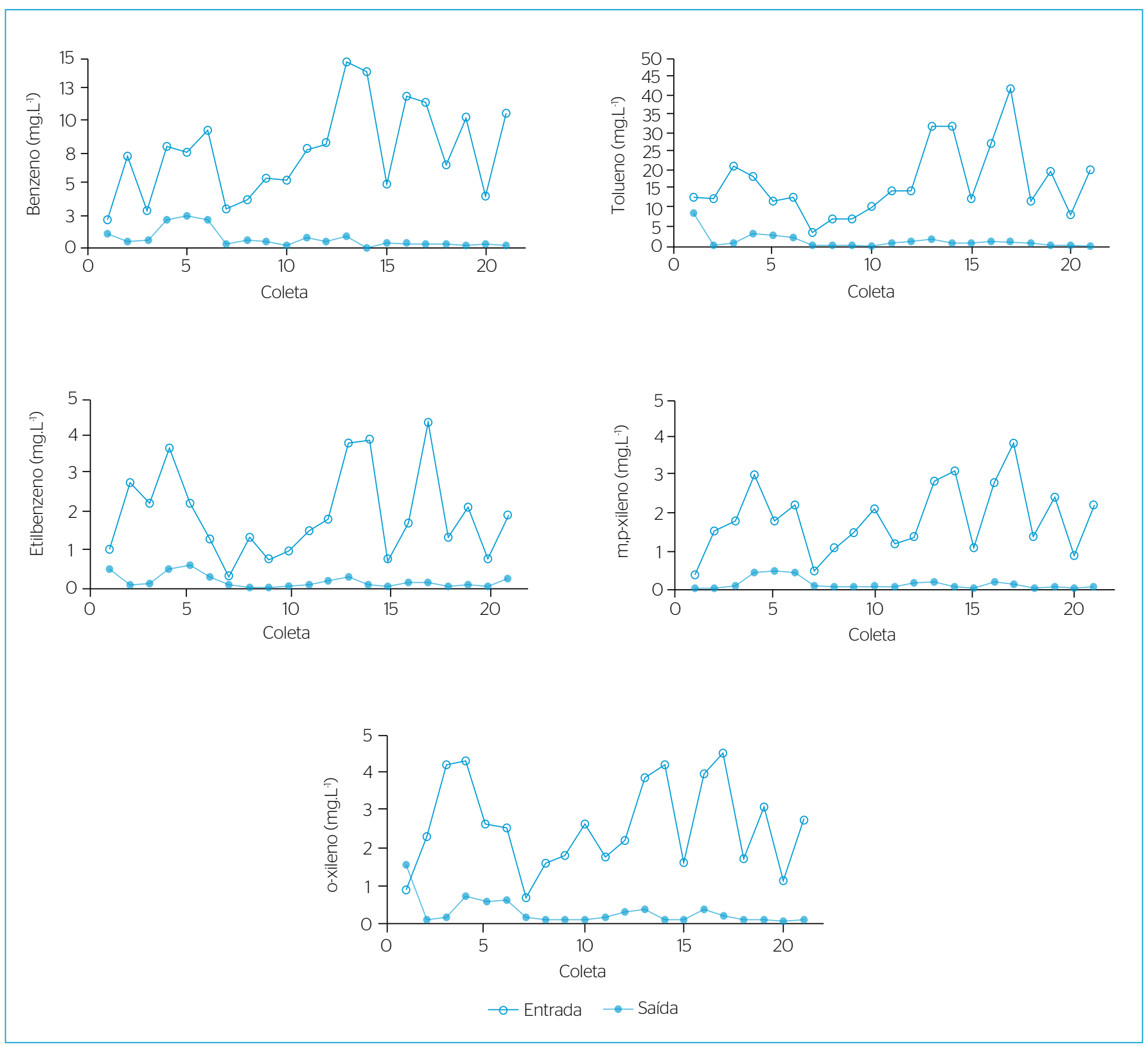

Figura 4 - Concentração de benzeno, tolueno, etilbenzeno e xileno no afluente e efluente ao reator de leito fixo e fluxo contínuo ao longo das coletas da Etapa II. 
Nardi et al. (2005) foram próximos dos obtidos na presente pesquisa, porém com a diferença de que os autores utilizaram o reator anaeróbio.

García-Peña et al. (2001) utilizaram reatores inoculados com o fungo Paecilomyces variotii em regime de batelada para remoção de BTEX na concentração de $35 \mathrm{mg} \cdot \mathrm{L}^{-1}$ de cada composto. Os resultados obtidos foram de completa remoção de tolueno em apenas dois dias de operação dos reatores, $90 \%$ de etilbenzeno em dez dias, $60 \%$ de m e p-xileno, 30\% de o-xileno e 45\% de benzeno após os dez dias de operação.

Os resultados demonstram que a utilização de reatores de fluxo contínuo é muito importante, pois potencializam os bons resultados que vêm sendo obtidos com a utilização de fungos, a maioria em regime de batelada como no experimento de García-Peña et al. (2001). Com isso, fica visível a eficiência do reator de leito fixo de biomassa fúngica e com fluxo contínuo.

Fazendo um comparativo entre as Etapas I e II, verificou-se que, no geral, a eficiência média de remoção dos compostos BTEX nessas etapas não apresentou valores muito distantes, ficando acima de 85\% na Etapa II. Na Etapa I, a menor eficiência média de remoção de BTEX foi de $79 \%$.

Segundo Espósito \& Azevedo (2004), a capacidade dos fungos de adaptarem rapidamente seu metabolismo a diferentes tipos de fontes de carbono é um fator essencial para sua sobrevivência. Essa flexibilidade se deve à produção de grande quantidade de enzimas intra $\mathrm{e}$ extracelulares não específicas, capazes de degradar uma série de compostos. Os fungos se apresentam como agentes eficientes na biorremediação graças a essas enzimas com grande capacidade catalítica e pela maior superfície de contato - propiciada pela exposição de suas hifas ao meio que contém poluentes.

Muitos fungos filamentosos são capazes de degradar compostos monoaromáticos por meio do sistema enzimático citocromo P-450 monoxigenase. Por esse sistema enzimático, ocorre a epoxidação do anel aromático para formar um intermediário instável, um óxido de areno. Esse óxido é imediatamente hidratado por uma epóxido hidrolase, formando o transdihidrodiol e, em seguida, por rearranjos não enzimáticos, os fenóis. A partir dos fenóis e do transdihidrodiol, os fungos podem produzir quinonas e, em alguns casos, conjugados de glicose, sulfato, xilose e ácido glicurônico (ESPÓSITO \& AZEVEDO, 2004).

É importante salientar que o ensaio de volatilidade realizado em condições abióticas mostrou que praticamente não ocorreu variação da concentração dos BTEX no meio. Verificou-se um aumento médio de 26 p.p. (pontos percentuais) da concentração, considerando o total de BTEX no final de 9 horas, o que foi justificado pela presença de etanol na gasolina, que teria aumentado a dissolução dos hidrocarbonetos aromáticos em meio aquoso (FERNANDES \& CORSEUIL, 1996). Esse fato acarreta no aumento da concentração desses hidrocarbonetos no efluente final, após maior tempo de contato, propiciado pelo tempo de permanência do fluxo de água contaminada no reator.
Isso é possível porque o processo tende a ocorrer lentamente na fase aquosa (NUNES \& CORSEUIL, 2007), de modo que, de acordo com os dados observados, não ocorreu perda considerada por volatilização.

No que tange à remoção de matéria orgânica, o percentual médio de remoção alcançado ao longo da Etapa II foi de 48\% e na Etapa I de $30 \%$, sendo o percentual médio de remoção da Fase 1 de $21 \%$ - ausência de nutrientes - e da Fase 2 - com nutrientes - de 41\%. A partir dos dados obtidos, verificou-se que a adição de nutrientes beneficiou sensivelmente a eficiência de remoção da matéria orgânica. Esse fato se deve não pela remoção desses compostos do meio - eles se encontravam em baixas concentrações - , e sim pelo benefício ao metabolismo fúngico que esses macro e micronutrientes proporcionaram. Segundo Espósito \& Azevedo (2004), os macronutrientes, como o nitrogênio, o fósforo e o enxofre, são essenciais para o metabolismo fúngico na síntese de macromoléculas celulares de interesse celular, e os micronutrientes, muitas vezes chamados de elementos traço, são importantes para cumprir as funções de coenzimas ou cofatores enzimáticos, para transferir elétrons em reações de óxido-redução e como reguladores osmóticos.

A análise estatística mostrou que houve diferença significativa nos percentuais de remoção de DQO comparando tanto as Fases 1 e 2 da Etapa I como as Etapas I e II $(\mathrm{p}<0,05)$. Foi indicado, ainda, que não houve prejuízo ao tratamento com a retirada da glicose, uma vez que sua presença no meio contribuía com o aumento da matéria orgânica a ser consumida, refletindo na menor eficiência de remoção da Etapa I.

Piubeli et al. (2012) avaliaram a remoção de DQO em efluentes resultantes da produção de petróleo utilizando bactérias isoladas do próprio efluente em reatores de bancada por um tempo reacional de quatro dias com e sem adição de nutrientes. A concentração de DQO inicial foi de $4300 \mathrm{mg} \cdot \mathrm{L}^{-1}$. No experimento sem adição de nutrientes a remoção de DQO foi de apenas $20 \%$, já no experimento com adição de $\mathrm{KH}_{2} \mathrm{PO}_{4}, \mathrm{NH}_{4} \mathrm{NO}_{3}$ e alanina, a remoção foi de $67 \%$. Esses resultados, assim como os da presente pesquisa, demonstraram a importância dos nutrientes para o melhor desempenho dos micro-organismos.

Além disso, a água contaminada com gasolina pode ter exercido toxicidade aos fungos, ainda em adaptação ao meio. Não apenas os BTEX são tóxicos, mas outros compostos presentes na gasolina, bem como subprodutos formados a partir da degradação dos substratos, contribuindo para o aumento da DQO efluente..

Pinheiro et al. (2008) utilizaram Aspergillus niger para a remoção de benzeno e DQO de matriz aquosa em reatores em batelada com biomassa dispersa. Foram avaliadas em três concentrações de benzeno (v/v): 10, 5 e 1\%. As remoções obtidas foram de 37, 76 e 34\%, respectivamente. Os valores de Pinheiro et al. (2008) foram alcançados em 5 dias de tempo reacional em batelada, enquanto que neste estudo foram alcançados em TDH de 12 horas.

Portanto, comparando com os resultados obtidos por Pinheiro et al. (2008), os resultados desta pesquisa apresentaram-se bastante 
favoráveis no tocante à remoção de matéria orgânica. Provavelmente a imobilização da biomassa fúngica, que, segundo Pietro et al. (2002), ajuda na adaptação do micro-organismo ao composto tóxico, tenha contribuído para resultados superiores.

Segundo Rodrigues et al. (2011), os micro-organismos assumem estratégias ecológicas para a assimilação de um substrato: uma delas é o cometabolismo. Segundo Khelifi et al. (2009), ao serem expostos aos compostos de estrutura complexa, eles utilizam uma fonte mais facilmente assimilável para a obtenção de energia, para só então cometabolizar as moléculas mais complexas. A adição de glicose assume, então, importante papel na biodegradação dos compostos recalcitrantes, sendo justificado seu uso na primeira etapa da pesquisa.

A retirada da glicose na segunda etapa foi justificada por representar economia no tratamento dos compostos alvo, tendo em vista que o próprio etanol presente na água contaminada serviria como cossubstrato. A gasolina brasileira possui aproximadamente $22 \%$ de etanol e esse migra para a fase aquosa, levando os compostos BTEX por cossolvência. O meio, então, não ficou sem uma fonte mais facilmente assimilável pelos fungos, resultando, assim, ainda que sem adição de glicose, em um bom percentual médio de remoção de matéria orgânica para a Etapa II — 48\%.

Quanto aos dados de fenóis, verificou-se remoção média de 46\%, sendo que houve coletas em que ocorreu aumento da concentração dos mesmos no efluente em relação ao afluente, como resultado da possível formação de fenol a partir da rota de degradação dos compostos BTEX. Nas coletas em que a concentração de fenol diminuiu, provavelmente ocorreu a metabolização do fenol e do transdihidrodiol e, a partir desses dois compostos, os conjugados de glicose, sulfato, xilose ou ácido glicurônico (DAS \& CHANDRAN, 2010).

Das \& Chandran (2010) afirmaram que na rota de degradação de compostos aromáticos por organismos eucarióticos como os fungos, um átomo da molécula de oxigênio presente no meio é incorporado ao substrato aromático, enquanto o outro átomo é reduzido à água. $\mathrm{O}$ óxido de areno formado pode ser metabolizado pela sua isomerização para formar fenol, que pode ser conjugado com sulfato, ácido glucônico ou glicose ou ser também metabolizado pelo fungo, conduzindo, principalmente, à formação de catecol e ácidos orgânicos. Por outra via, o óxido de areno conduz a formação de transdihidrodiol, que pode ser convertido a catecol, metabólito chave da metabolização de vários compostos aromáticos pelos micro-organismos, pois a partir dele ocorre a ruptura do anel aromático para futura assimilação.

Os resultados de sulfato, obtidos na Etapa II, podem indicar que a degradação do fenol tenha ocorrido pela rota de metabolização específica via catecol, tendo o efluente do reator apresentado concentração maior que o afluente na maioria das coletas monitoradas. Provavelmente, isso se deu em função da formação de conjugados de sulfato a partir do fenol e transdihidrodiol oriundos da metabolização do BTEX, conforme relatado por Espósito \& Azevedo (2004).
Os fungos já haviam armazenado o sulfato no início da operação e, em alguns períodos de carência do nutriente, esse era utilizado à medida que ia ocorrendo a formação de fenol e transdihidrodiol para a formação dos conjugados. Segundo Leite et al. (2006), os vacúolos são as estruturas fúngicas responsáveis pela função de armazenamento de nutrientes que podem ser acumulados ou liberados de acordo com as necessidades metabólicas do micro-organismo.

Em relação ao $\mathrm{pH}$, o valor médio deste no afluente e no efluente da Fase 1 da Etapa I foi de 4,0. Já na Fase 2 dessa mesma etapa, o pH médio de entrada também foi 4,0, e o pH médio da saída foi 3,0.

Segundo Rodrigues (2006), como resultado da degradação da matéria orgânica presente, os fungos realizam a produção de ácidos orgânicos como subprodutos de degradação, e esse fato acarreta na diminuição do pH, como foi observado na Fase 2 da Etapa I. Com isso, os fungos, possivelmente, encontraram melhores condições nutricionais e se adaptaram à carga tóxica exercida pelos poluentes presentes no meio, promovendo a degradação da matéria orgânica. Foi obtido o melhor percentual médio de remoção (41\%) em comparação com a fase anterior, o que ficou refletido na diminuição do $\mathrm{pH}$ do efluente.

Na Etapa II, em que não houve a adição de glicose como cossubstrato, o pH variou mais acentuadamente em relação à etapa anterior e apresentou, em termos de valores médios, os valores 3,9 e 2,9 para afluente e efluente, respectivamente. A retirada da glicose pode ter influenciado na menor homogeneidade dos resultados, ocorrendo uma maior variação nos valores de $\mathrm{pH}$.

O ensaio abiótico de adsorção revelou que a remoção de BTEX deveu-se, principalmente, à biodegradação. Na Tabela 3, são mostrados os resultados de massa total de remoção de BTEX em biorreator e devido à adsorção em suporte de polipropileno. A capacidade de adsorção do suporte de imobilização foi muito baixa.

A remoção de BTEX em biorreator, de $479,7 \mathrm{mg}$ de benzeno, 976,3 mg de tolueno, 107,9 mg para etilbenzeno, 105,7 mg de m e p-xileno e 144,2 mg de o-xileno, foi superior à capacidade máxima do suporte para adsorver os compostos, provando que a sua remoção era devido à biodegradação.

Tabela 3 - Massa total de BTEX removida no bioreator durante a operação e a massa removida por adsorção em meio suporte de polipropileno.

\begin{tabular}{l|c|c|c} 
Poluente & $\begin{array}{c}\text { Máxima } \\
\text { capacidade de } \\
\text { adsorção pelo } \\
\text { meio suporte } \\
\left(\mathbf{m g . g}^{-1}\right)\end{array}$ & $\begin{array}{c}\text { Massa total de } \\
\text { BTEX removida } \\
\text { no bioreator } \\
(\mathbf{m g})\end{array}$ & $\begin{array}{c}\text { Massa total de } \\
\text { BTEX removi- } \\
\text { da pelo meio } \\
\text { suporte }(\mathrm{mg})\end{array}$ \\
\hline Benzeno & 0,148 & 479,700 & 6,660 \\
\hline Tolueno & 0,044 & 976,300 & 2,000 \\
\hline m, p-xilbenzeno & 0,061 & 107,900 & 0,600 \\
\hline o-xileno & 0,007 & 105,700 & 0,340 \\
\hline
\end{tabular}

BTEX: benzeno, tolueno, etilbenzeno e xilenos. 
A contagem de fungos e bactérias revelou que na primeira etapa a população de fungos foi superior à bacteriana, respectivamente de $40 \times 10^{3}$ e de $2 \times 10^{1}$ UFC. $\mathrm{mL}^{-1}$, sendo que na Etapa II, quando não havia glicose no meio, não foi visualizada nenhuma colônia bacteriana.

Miranda et al. (2010) realizaram um trabalho em reatores inoculados com fungos e em condições abióticas, tendo verificado que, nos reatores que receberam etanol, houve pouca contaminação do meio com bactérias. Portanto, no presente estudo, a presença de etanol na composição da gasolina também pode ter contribuído para inibir a contaminação do meio por bactérias, além de ser um cossubstrato mais eficiente para a degradação específica de etilbenzeno.

É importante ressaltar que ainda foi detectada outra espécie fúngica, além da espécie inoculada inicialmente. Provavelmente, esse fungo seja proveniente do ar ou mesmo da gasolina que era utilizada para o experimento.
Nas Figuras 5 e 6, são apresentadas imagens do Aspergillus niger e da espécie contaminante não identificada em microscópio óptico com aumento de 40 vezes. O fungo contaminante não foi identificado pelos métodos tradicionais de identificação disponíveis no laboratório e não se teve condições de proceder à sua identificação com técnicas de biologia molecular.

Em estudos realizados por Cerniglia (1997) e Jacques et al.(2007), vários fungos dos gêneros Cunnighamella, Phanerochaete, Fusarium, Candida, Penicillium, Pleorotus, Trametes, Aspergillus, Bjerkandera e Chrysosporium se destacaram como possuidores de habilidade para degradar hidrocarbonetos aromáticos. Esses relatos endossam a habilidade do Aspergillus e do Penicillium em degradar os compostos BTEX, como observado no presente trabalho. O consórcio de micro-organismos na biorremediação de áreas contaminadas com BTEX tem sido muito explorado, pois, segundo Wolicka et al. (2009), a utilização de apenas uma espécie de micro-organismo na biodegradação de solos

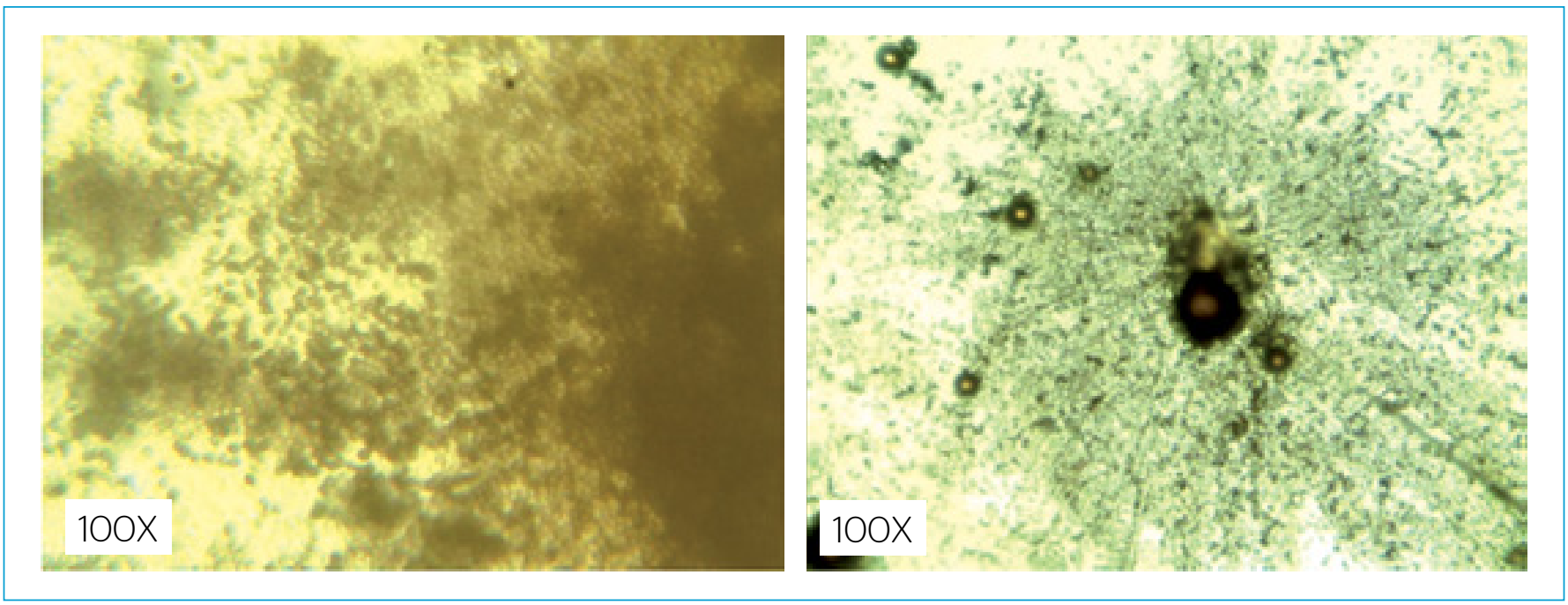

Figura 5 - Detalhe da estrutura do Aspergillus niger presente no biofilme cuja amostra foi removida no último dia de operação do reator.
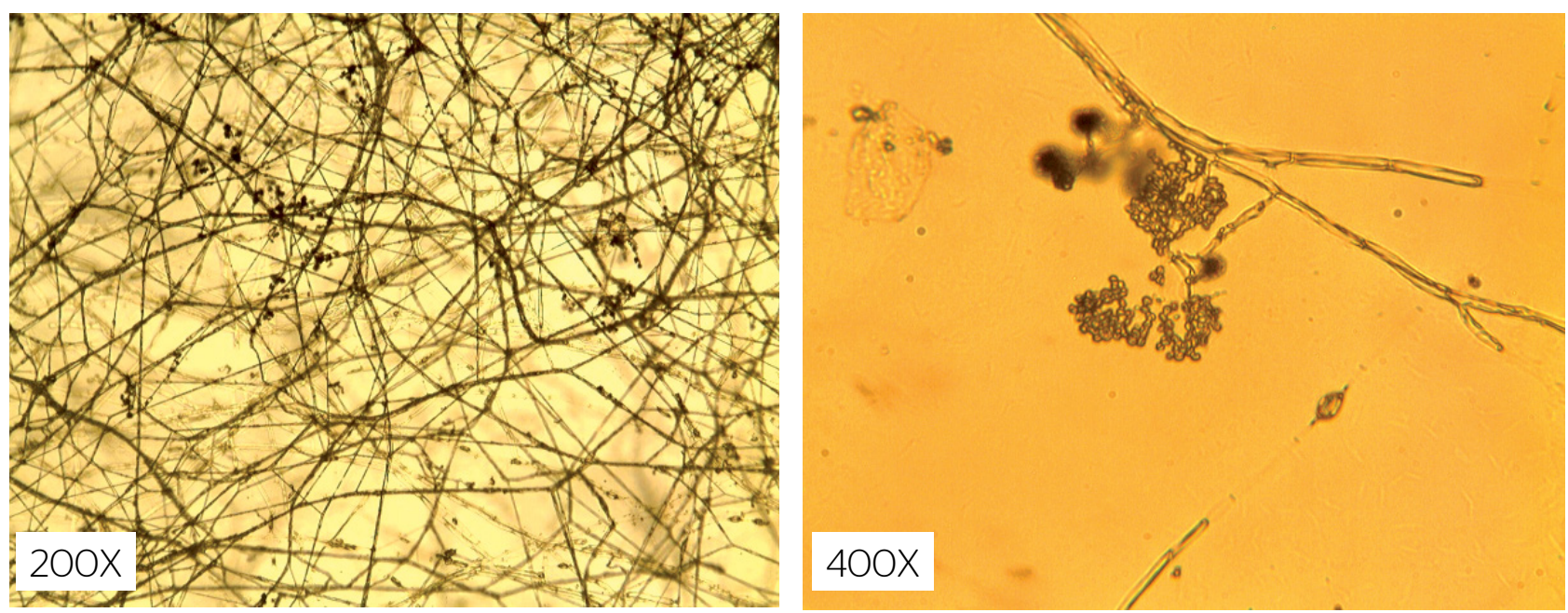

Figura 6 - Detalhe do fungo não identificado encontrado em amostra do biofilme removida do reator no último dia de operação. 
contaminados por compostos recalcitrantes possui pouca capacidade de decompor simultaneamente um ou vários hidrocarbonetos. Por isso, para uma biorremediação efetiva de áreas contaminadas por derivados de petróleo, é necessária a aplicação de comunidades mistas de micro-organismos.

\section{CONCLUSÕES}

A operação do reator de escoamento contínuo com biomassa imobilizada de Aspergillus niger AN400 foi influenciada pela glicose quanto à remoção de benzeno e etilbenzeno, obtendo-se maior remoção desses compostos, respectivamente, na presença e ausência de glicose (96\%). $\mathrm{Na}$ sua ausência de glicose, o etanol, oriundo da composição da gasolina brasileira, cumpriu com o papel de cossubstrato, contribuindo para a remoção do etilbenzeno, além de auxiliar na inibição da população bacteriana e favorecer o estabelecimento de microbiota fúngica.

Não houve diferença significativa quanto ao uso de glicose ou etanol visando à remoção de tolueno e xilenos.

Na Etapa I, a eficiência de remoção dos BTEX ficou próxima, independente da presença ou ausência de nutrientes no meio, sem diferença significativa, conforme aplicação do teste estatístico.

A não adição de nutrientes nas primeiras coletas (Fase 1) foi necessária em face do problema de colmatação observado, de forma que a presença de nutrientes melhorou a remoção de matéria orgânica, ainda que a eficiência registrada tenha sido baixa (40\%). Esse fato foi motivado pela possível formação de subprodutos, particularmente compostos fenólicos oriundos da degradação dos BTEX, segundo rota de degradação, os quais persistiram no efluente final.

\section{REFERÊNCIAS}

APHA - American Public Health Association. (2005) Standard methods for the examination of water and wastewater. 21. ed. Washington: American Public Health Association. 1368p.

ABNT - Associação Brasileira de Normas Técnicas (1989). NBR 10740: Água - Determinação de fenol total . Método de ensaio.

BOM, E.P.S.; FERRARA, M.A.; CORVO, M.L. (2008) Enzimas em biotecnologia: produção, aplicações e mercado. Rio de Janeiro: Interciência. 506p.

BONO, R.; BUGLIOSI, H.E.; SCHILIRÓ, T.; GILLI, G. (2001) The Lagrange Street story: the prevention of aromatics air pollution during the last nine years in a European city. Atmosphere Environmental, v. 35, p. 107-113.

CERNIGLIA, C.E. (1997) Fungal metabolism of polycyclic aromatic hydrocarbons: past, present and future applications in bioremediation. Journal of Industrial Microbiology \& Biotechnology, v. 19, n. 5, p. 324-333.

CHENG, Z.; LU, L.; KENNES, C.; YU, J.; CHEN, J. (2016) Treatment of gaseous toluene in three biofilters inoculated with fungi/bacteria: microbial analysis, performance and starvation response. Journal of Hazardous Materials, v. 303, p. 83-93.

D'ANNIBALE, A.; RICCI, M.; QUARANTINO, D.; FEDERITI, F.; FENICE, M. (2004) Panus tigrinus efficiently removes phenols, color and organic load from olive-milkwastwater. Research in Microbiology, v. 155, n. 7. p. 596-603.

DAS, N. \& CHANDRAN, P. (2010) Microbial degradation of petroleum hydrocarbons contaminants: an overview. Biotechnology Research International, v. 2011

ESPÓSITO, E. \& AZEVEDO, J.L. (2004) Fungos: uma introdução à biologia, bioquímica e biotecnologia. Caxias do Sul: Educs. 510p.
FERNANDES, M. \& CORSEUIL, H.X. (1996) Contaminação de águas subterrâneas por derramamento de gasolina: efeito cossolvência. In: Simpósio Ítalo-Brasileiro de Engenharia Sanitária e Ambiental, 3., Gramado. Anais... Gramado: Editora Ulbra.

GARCÍA-PEÑA, E.I.; HERNANDEZ, H.; FAVELA-TORRES, E.; AURIA, R.; REVAH, S. (2001) Toluene biofiltration by the fungus Scedosporium apiospermum TB1. Biotechnology and Bioengineering, v. 76, n. 1, p. 61-69.

GRIFFIN, D.H. (1994) Fungal physiology. 2. ed. New York: Wiley-Liss. 458p.

JACQUES, R.J.S.; BENTO, F.M.; ANTONIOLLI, Z.I.; CAMARGO, F.A.O. (2007) Biorremediação de solos contaminados com hidrocarbonetos aromáticos policíclicos. Ciência Rural, v. 34, n. 4, p. 1191-1201.

KAPDAN, I.K.; KARGI, F. (2002) Simultaneous biodegradation and adsorption of textile dyestuff in an activated sludge unit. Process Biochemistry, n. 37, p. 973-981.

KHELIFI, E.; AYED, L.; BOUALLAGUI, H.; TOUHAMI,Y.; HAMDI, M. (2009) Effect of nitrogen and carbon sources on Indigo and Congo red decolourization by Aspergillus alliaceus strain 121C. Journal of Hazardous Materials, v. 163, p. 1056-1062.

LEITE, C.L.; GROPOSO, C.; SANTOS, E.R.D.; FIGUEIREDO, N.F.; GODINHO, P.S.; ABRÃO, R.L. (2006) A particularidade de ser um fungo - I. Constituintes celulares. Biotemas, v. 19, n. 2, p. 17-27.

LEMOS, J.L.S.; OLIVEIRA, S.D.; BARROS, C.A.; REICHE, A.P. (2008) Fungos filamentosos: agentes de degradação de petróleo e de hidrocarbonetos aromáticos policíclicos (HAPs). Rio de Janeiro: CETEM/MCT. (Série Tecnologia Ambiental). 
LIU, R.; FENG, H.; WANG, X:; ZHANG, C; ZHANG, K.; LAl, R. (2008) Pseudomonas duriflava sp. nov., isolated from a desert soil. International Journal of Systematic and Evolutionary Microbiology, v. 58, p. 1404-1408.

LOPES, M.; OLIVEIRA, P.C.C.; ANDRADE, M.V.F; ARAÚJO, R.S.; MARINHO, G.; RODRIGUES, K.A. (2011) Remoção de macronutrientes de efluente de indústria de castanha de caju por uso de reator aeróbio em batelada com inóculo fúngico. Engenharia Sanitária e Ambiente, v. 16, n. 1, p. 17-26.

MIRANDA, F.M.; GABRIELE, C.; SILVA, K.M.L.; WANDERLEY, C.R.P.; MARINHO, G.M.; RODRIGUES, K.A. (2O10) Emprego de etanol como cossubstrato em reator com biomassa imobilizada de Aspergillus niger AN400 para remoção de corante vermelho do congo. In: Congresso de Pesquisa e Inovação da Rede Norte Nordeste de Educação Tecnológica, 5., Maceió. Anais..., Maceió.

NARDI, I.R.; RIBEIRO, R.; ZAIAT, M.; FORESTI, E. (2005) Anaerobic packed-bed reactor for bioremediation of gasoline-contaminated aquifers. Process Biochemistry, v. 40, n. 2, p. 587-592.

NUNES, C.C. \& CORSEUIL, H.X. (2007) Importância do etanol na atenuação natural de águas subterrâneas impactadas por gasolina. Engenharia Sanitária e Ambiental, v. 12, n. 3, p. 259-265.

PIETRO, M.B.; HIDALGO, A.; SERRA, J.L.; LLAMA, M.J. (2002) Degradation of phenol by Rhodococcus erithropolis UPV1 imobilizede on biolite in a packed-bed reactor. Journal of Biotechnology, v. 97, n. 1, p. 1-11.

PINHEIRO, Z;; DAMASCENO, E.; MARINHO, G.; RODRIGUES, K.; MARINHO, G. (2008) Remoção de benzeno e matéria orgânica carbonácea de matriz aquosa por Aspergillus niger AN4OO em reatores em batelada. In: Congresso de Pesquisa e Inovação da Rede Norte Nordeste de Educação Tecnológica Fortaleza, 3., Fortaleza, Anais..., Fortaleza. CD-ROM.

PIUBELI, F; GROSSMAN, M.J.; FANTINATTI-GARBOGGINI, F; DURRANT, L.R. (2O12) Enhanced reduction of COD and aromatics in petroleumproduced water using indigenous microorganisms and nutrient addition. International Biodeterioration \& Biodegradation, v. 68, p. 78-84.

PRENAFETA BOLDU, F.X. (2002) Growth of fungi on volatile aromatics hydrocarbons: environmental technology perspectives. Tese (Doutorado) - Wageningen University,Wageningen.115p.
RENE, E.R.; MOHAMMAD, B.T; VEIGA, M.C.; KENNES, M.C. (2012) Biodegradation of BTEX in a fungal biofilter: influence of operationals parameters, effect of shock-loads and substrate stratification. Bioresource Technology, v. 116, p. 204-213.

RODIER, J. (1975) L'analyse de L'eau: eaux naturelles, eaux residuls, eaux de mer. 5. ed. Paris: Dunot. 692p.

RODRIGUES, K.A. (2006) Uso de reatores biológicos com fungos para remoção de fenol de água residuária sintética.145p. Tese (Doutorado) - Universidade de São Paulo, São Paulo.

RODRIGUES, K.A.; SILVA, K.M.L;; SILVA, G.M.; LIMA, P.C.C.; WANDERLEY, C.R.P.; SILVA, G.M. (2011) Remoção de corante por uso de Aspergillus niger AN4OO em reator em bateladas sequenciais. Química Nova, v. 34, n. 7, p. 1119-1123.

SAMPAIO, G.M.M.S. (2005) Remoção de metil paration e atrazina em reatores de bancada com fungos. 150p. Tese (Doutorado) Departamento de Hidráulica e Saneamento, Escola de Engenharia de São Carlos, Universidade de São Paulo, São Carlos.

SILVA, S.P. (2008) Degradação anaeróbica de BTEX em reatores alimentados com água contaminada por gasolina. Dissertação (Mestrado) - Universidade Federal de Pernambuco, Recife.

TAKESHITA, E.V. (2006) Adulteração de gasolina por adição de solventes: análise dos parâmetros físico-químicos. Dissertação (Mestrado) - Centro Tecnológico em Engenharia Química, Universidade Federal de Santa Catarina, Florianópolis.

TIBURTIUS, E.R.L.; ZAMORA, P.P.; LEAL, E.S. (2004) Contaminação de águas por BTX e processos utilizados na remediação de sítios contaminados. Química Nova, v. 27, n. 3, p. 441-446.

WANG, F.Q.; XIE, H.; CHEN, W.; WANG, E.T.; DU, F.G.; SONG, A.D. (2O13) Biological pretreatment of corn stover with ligninolytic enzyme for high efficient enzymatic hydrolysis. Bioresource Technology, v. 144, p. 572-578.

WOLICKA, D.; SUSZEK, A.; BORKOWSKI, A.; BIELECKA, A. (2009) Application of aerobic microorganisms in bioremediation in situ of soil contaminated by petroleum products. Bioresource Technology, v. 100, n. 13, p. 3221-3227. 